Djurdja Kerkez ${ }^{1 *}$, Milena Bečelić-Tomin ${ }^{1}$, Božo Dalmacija ${ }^{1}$, Dragana Tomašević Pilipović ${ }^{1}$, Miljana Prica', Anita Leovac Maćerak ${ }^{1}$, Nataša Slijepčević ${ }^{1}$

${ }^{1}$ University of Novi Sad, Faculty of Sciences, Department for Chemistry, Biochemistry and Environmental Protection, Section for Chemical Technology and Environmental Protection, Novi Sad, Serbia, ${ }^{2}$ Universityof Novi Sad, Faculty of Technical Sciences, Novi Sad, Serbia
Scientific paper

ISSN 0351-9465, E-ISSN 2466-2585

UDC: $628.336 .1 / .8$

doi: $10.5937 /$ ZasMat $1603439 \mathrm{~K}$

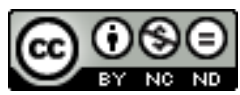

Zastita Materijala 57 (3) 439 - $448(2016)$

\title{
Treatment of pyrite cinder sludge after usage in dye degradation - Feasibility study
}

\begin{abstract}
Over the last couple of years greener concept in hazardous waste management is gaining increasing relevance. This term refers to the processes and activities that have little or negligible impact on the environment. The aim of this study is to systematically quantify the physical and chemical properties of the solidified/stabilized (S/S) sludge generated in dye effluent treatment, when pyrite cinder is used as catalytic iron source in the modified heterogeneous Fenton process. $S / S$ treatment was performed by using two clay materials (kaolinite and bentonite) and lime in order to immobilize $\mathrm{Cu}, \mathrm{Pb}$ and $\mathrm{Zn}$ present in the sludge. Microwave assisted sequential extraction procedure was employed to assess potential metal mobility and risk to the environment. In order to determine the long-term behaviour of the S/S mixtures, the semi-dynamic ANS 16.1 leaching test was performed. S/S effectiveness was evaluated by measuring the cumulative fractions of leached metals, effective diffusion coefficients - De and leachability indices - LX. Scanning electron microscope (SEM) and X-ray diffraction (XRD) were implemented to elucidate the mechanisms responsible for immobilization of the $\mathrm{Cu}, \mathrm{Pb}$ and $\mathrm{Zn}$. This analysis confirmed the formation of compact matrices and pozzolanic products. Compressive strength measurement also proved the treatment efficacy. It can be concluded that the S/S technique has significant potential for solving the problem of hazardous industrial waste and its safe disposal.
\end{abstract}

Keywords: industrial waste, long-term leaching, low-cost binders, compressive strength, sustainable waste management.

\section{INTRODUCTION}

Hazardous industrial wastes are an inevitable source of environmental pollution. Leachates from these wastes could contaminate potable water sources and affect human health. One of the potential hazardous waste problems in Serbia is pyrite cinder generated in sulfuric acid production. A high content of iron oxide in the form of hematite and magnetite is making this waste convenient for exploiting these useful components in certain processes. One of the possibilities of its use is as a source of catalytic iron in the modified heterogeneous Fenton processes in wastewater treatment, especially in dye effluent treatment [1-3]. If this waste material is the source of iron it can reduce the cost of the application of these proces

\footnotetext{
${ }^{*}$ Corresponding author: Djurdja Kerkez

E -mail addresse: djurdja.kerkez@dh.uns.ac.rs;

Paper received: 26.03.2016.

Paper accepted: 3.05.2016.

Paper is available on the website:

www.idk.org.rs/journal
}

ses, and potentially enable the use of wastes for the purpose of waste water treatment. After the utilization of this waste material in a heterogeneous Fenton process, generated sludge is mainly composed of the used pyrite cinder. As pyrite cinder also contains traces of toxic/hazardous heavy metals such as $\mathrm{Cu}, \mathrm{Zn}, \mathrm{Pb}$, and As [4-6], generated sludge may be toxic and cannot be disposed of directly without previous treatment.

Stabilization and solidification $(\mathrm{S} / \mathrm{S})$ is characterized as the best available technique for the treatment of hazardous and other waste types $[7,8]$, and has been extensively used as the final treatment step prior to the disposal of industrial wastes. Typically, the stabilization processes also involve some form of the physical solidification [9]. During S/S applications the toxic constituents which are present in the waste are physically and chemically fixed [10]. By finding suitable $S / S$ methods for a particular hazardous waste, we can achieve not only successful disposal of hazardous waste, but after proper modification, we can also provide a possibility for its next utilization in the 
building industry [9]. Wide varieties of materials have been used as S/S agents. Cement, calciumhydroxide, calcium oxide and other pozzolanic materials are widely used and thoroughly tested in S/S treatment of soil contaminated with arsenic and other metals, but the published data on the treatment of hazardous waste contaminated with metals are relatively incomplete [11, 12]. Clays in the $S / S$ treatments are used because they are cheap, abundant and good adsorbents for metal ions in aqueous solutions, due to a high cation exchange capacity and high specific surface area. Literature data show wide use of clay in removing metals from various effluents, such as industrial and process water, as well as in the treatment of soil $[13,14]$ but on the other hand, data on their use in remediation of sludge and wastes are rather scarce. Quantifying the environmental impact of $\mathrm{S} / \mathrm{S}$ materials in real environmental scenarios is crucial for selecting proper disposal and reuse alternatives and for certification of immobilization technologies. The performance of $S / S$ treated wastes is generally measured in terms of leaching tests. Semi-dynamic leaching test, such as ANS 16.1, provides substantially more information regarding the "real time" rate at which heavy metals are released from the solidified product as compared to other short-term leaching tests [15]. The leaching results extend over a 90-day period instead of a single result at the end of the test.

The main objectives of this study can be summarized as follows: (1) assessing the characteristics of generated sludge from dye effluent treatment and evaluating its environmental risk (metal distribution and pseudo-total metal content), (2) $S / S$ treatment of generated sludge with the addition of clays and lime; (3) defining metal distribution and evaluation of environmental risk in selected S/S mixtures according to microwave assisted sequential extraction procedure; (5) investigation of $\mathrm{S} / \mathrm{S}$ matrices binding mechanisms by scanning electron microscope (SEM) and X-ray diffraction (XRD) and their potential usage by determining compressive strength.

\section{METHODS AND MATERIALS}

Used sludge was obtained after heterogeneous Fenton treatment of dye effluent, where pyrite cinder was used as catalytic iron source. For this treatment pyrite cinder was obtained from IHP "Prahovo" A.D., Serbia. Lime used was commercially purchased $(\mathrm{CaO} \geq 99 \%)$, as well as kaolin and bentonite (consisting mostly of montmorillonite). Structural characteristics of these clays were further determined by adsorption-desorption analysis on the analyzer Autosortb ${ }^{T M} I_{2}$, Quantachrome Instruments, USA). Also, the cation exchange capacity (CEC) was determined according to USEPA 9080, 1986 [16].

\subsection{Initial sludge characterization and sample preparation}

In order to determine pseudo total metal content in raw sludge sample and selected $\mathrm{S} / \mathrm{S}$ mixtures US EPA standard method [17] was employed on microwave digestion unit Mileston Stare E. Also initial microwave assisted sequential extraction was performed as described in [18, 19].

All materials were first dried at $105{ }^{\circ} \mathrm{C}$ to constant mass and then mixed in established proportions, in order to create stable and durable $\mathrm{S} / \mathrm{S}$ matrices. Samples were designated by capital letter ( $\mathrm{P}$ : sludge, $\mathrm{B}$ : bentonite, $\mathrm{K}$ : kaolinite, and $\mathrm{L}$ : lime) followed by a number, indicating the percent weight of the given attribute. The content of each material was expressed as a percentage of the total solids weight. Solidified and stabilized samples were prepared according to ASTM D1557-00 (2000) [20]. After 28 days of curing, the monolithic samples were subjected to the leaching ANS 16.1 procedure and further characterization.

\subsection{ANS 16.1 test}

The long-term leachability of $\mathrm{Cu}, \mathrm{Pb}$ and $\mathrm{Zn}$ from the $S / S$ treated materials was evaluated using the ANS method 16.1 [21]. By applying this test we get the cumulative fraction of metals leached versus time. Mathematical diffusion model based on Fick's second law is used to evaluate the leaching rate as a function of time. The ANS has standardized the Fick's law-based mathematical diffusion model as follows:

$$
D e=\pi\left[a_{n} / A_{O} /(\Delta t)_{n}\right]^{2}[V / S]^{2} T_{n}
$$

where $a_{n}$ is the contaminant loss $(\mathrm{mg})$ during the particular leaching period with subscript $n ; A_{0}$ is the initial amount of contaminant present in the specimen $(\mathrm{mg}) ; V$ is the specimen volume $\left(\mathrm{cm}^{3}\right) ; S$ is the surface area of specimen $\left(\mathrm{cm}^{2}\right) ; \Delta t_{n}$ is the duration of the leaching period in seconds; $T_{n}$ is the time that elapsed to the middle of the leaching period $n(\mathrm{~s})$, and $D \mathrm{e}$ is the effective diffusion coefficient $\left(\mathrm{cm}^{2} \mathrm{~s}^{-1}\right)$.

The leachability index (LX), which is a parameter directly derived from the ANS 16.1 test results, is currently used by Environment Canada [22] as a performance criteria for the utilization and disposal of treated waste.

The LX is calculated using the diffusion coefficient obtained from Eq. (1). It is the average of the negative logarithm of the effective diffusivity terms (expressed in $\mathrm{cm}^{2} \mathrm{~s}^{-1}$ ). Therefore, the leachability index is defined as follows:

$$
L X=1 / m \sum_{n=1}^{m}\left[-\log \left(D_{e}\right)\right]_{n}
$$

Where $n$ is the number of the particular leaching period, and $m$ is the total number of individual 
leaching periods. LX values can be taken as a criterion for the use and disposal of $S / S$ treated wastes. For $L X$ values above 9 , the treatment is considered efficient and $\mathrm{S} / \mathrm{S}$ treated wastes adequate for "controlled use". For LX values between 8 and $9, S / S$ treated waste can be disposed of on a sanitary landfills. S/S waste with LX values of less than 8 is considered unsuitable for disposal [22, 23, 24].

Samples were prepared and leachate was collected and replaced according to the ANS 16.1 test. Metal content was determined by atomic absorption spectrometry AAS (Perkin Elmer AAnalyst TM 700) according to standard procedures $[25,26] . \mathrm{pH}$ and conductivity were measured in all leachates after the periodic collection, and prior to metal determination by using WTW $\mathrm{pH} 1970 \mathrm{i} \mathrm{pH}$ meterandinoLabCond7110conductometer.

\subsection{Characterization on $S / S$ mixtures}

To comprehend the mechanism of metal immobilization and other micro structural properties, $\mathrm{X}$ ray diffraction (XRD) and scanning electron microscope (SEM) analyses were performed on the prepared monolithic matrices after 28 days of age. The monolithic matrices were crushed and dried, ground to powder and then subjected to XRD and SEM analyses. Matrices with the highest clay content were characterized. For the XRD data collection a Philips PW1710 automated X-ray powder diffractometer was used. SEM photographs of the samples were carried out on a Jeol, JSM6460LV with INCA X sight program. Compressive
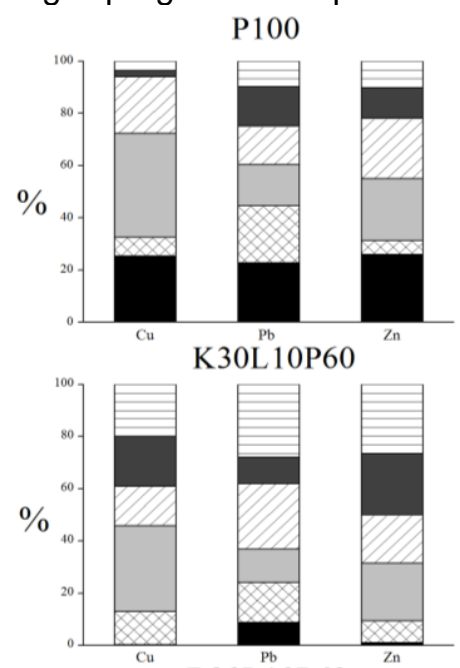

B30L $\stackrel{\text { Pb }}{10 P 60}$

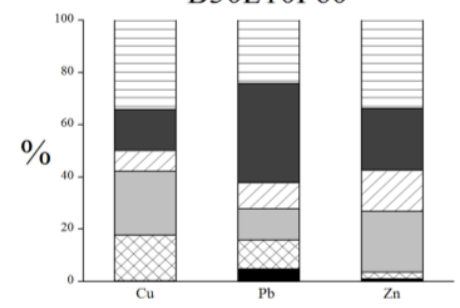

strength was determined by using a penetrometer which measures the penetration resistance of undisturbed samples in $\mathrm{kPa}$. The results are interpreted according to Patel and Pandey, 2012 [27] and del Valle-Zermeño et al. 2013 [28].

\section{RESULTS AND DISCUSSION}

Determination of pseudo total metal content showed that in raw sludge sample there is 0.06 $\mathrm{gkg}^{-1}$ of $\mathrm{Cu}, 0.30 \mathrm{gkg}^{-1}$ of $\mathrm{Pb}$ and $0.20 \mathrm{gkg}^{-1}$ of $\mathrm{Zn}$. As national legislation still does not use pseudototal metal content for waste characterization, these values were compared with the limit values set by the EPA 658/09, 2009 [29]. According to measured values, these metals greatly surpass prescribed limit values based on which raw sludge can be considered as hazardous waste.

The results obtained by performing sequential extraction on raw sludge sample as well as on selected S/S mixtures are summarized in Fig. 1. On the $y$-axis the percentages of extracted metals were presented in relation to the pseudo total metal content. According to risk assessment code (RAC) if a soluble and exchangeable fraction is $<1 \%$, there is no risk for the environment, $1-10 \%$ exhibits low risk, $11-30 \%$ medium risk, $31-50 \%$ high risk, and $>75 \%$ very high risk. In raw sludge sample percentages of extracted metals in soluble and exchangeable fraction are 44.5, 32.4 and $31.3 \%$ for $\mathrm{Pb}, \mathrm{Cu}$ and $\mathrm{Zn}$ respectively, posing a high risk to the environment $[30,31]$.

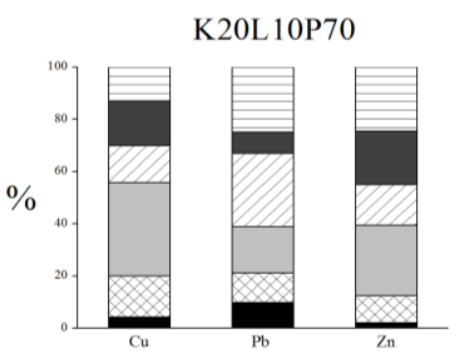

B20L 10 P 70
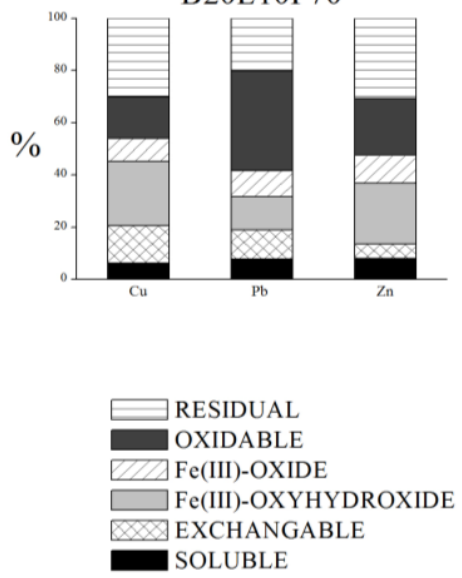

Figure 1 - Metal distribution in raw sludge sample and selected S/S mixtures 
Metals in these fractions are the most mobile and the most easily biologically accessible in the environment [32, 33]. Their presence in these phases increases the possibility of contamination of groundwater and surface water near the disposal site of such waste [34]. By comparing the results of the sequential extraction procedure of raw sludge sample and obtained S/S mixtures, a reduction of all metals in soluble and exchangeable phase can be observed. All S/S mixtures represent moderate or low risk to the environment. Same behavior can be observed when comparing mixtures with different content of appropriate clay. Increase in clay percentage reduces the metal content in soluble and exchangeable fraction, while the metal content in oxidable and especially in the residual fraction increases [35, 36].It may be noted that $\mathrm{Pb}$ is more prevalent in soluble and exchangeable fraction compared to other two metals. This can be explained by assuming that the alkalinity of the environment, due to the usage of lime, contributes to such effect, ie. the formation of the soluble hydroxide anion [37, 38].

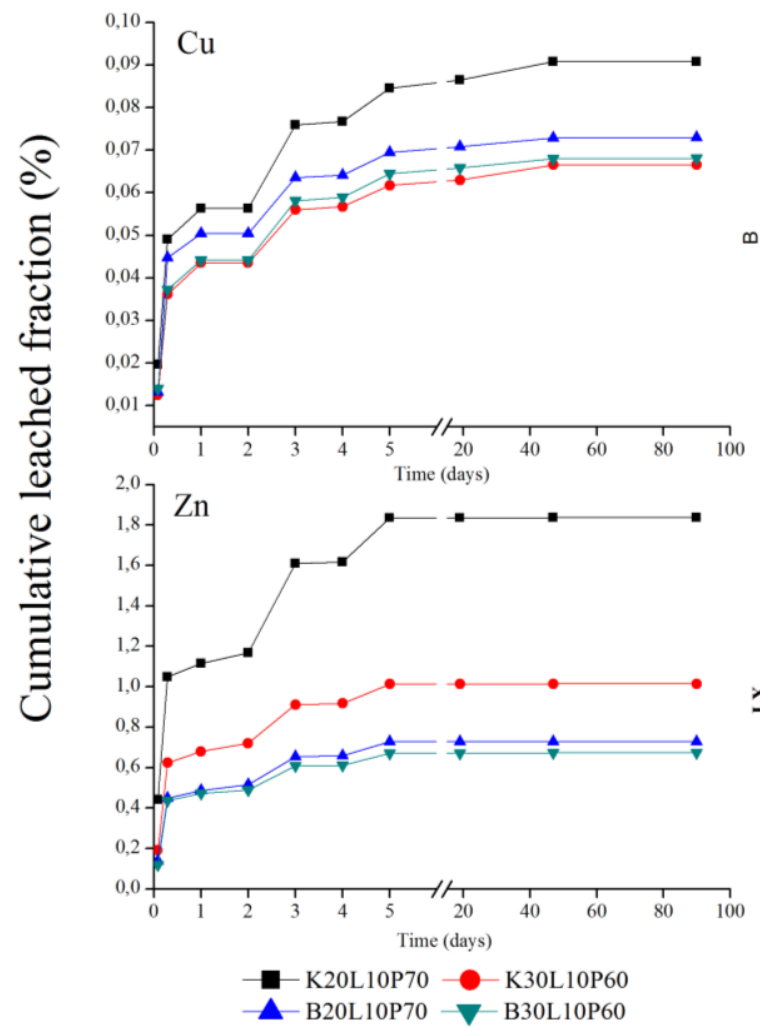

\subsection{ANS 16.1 test}

The cumulative values of leached $\mathrm{Cu}, \mathrm{Pb}$ and $\mathrm{Zn}$ from specimens treated with lime and clays are presented in Figure 2. If the percentages of leached metals are used as efficiency criteria, then it can be concluded that the treatment with clays and lime is very efficient [39]. With the increased share of clay in the S/S mixtures, there has been a reduction in the leaching of metals, which is consistent with the literature data $[11,8]$. If one compares the leached metal fractions from the $S / S$ mixture in terms of different types of clay it can lead to the conclusion that the efficiency of bentonite is slightly higher than kaolinite. These results are consistent with established structural characteristics of the applied clays. Namely BET specific surface area of bentonite $\left(39.6 \mathrm{~m} \mathrm{~g}^{2}\right.$ ) is almost triple than kaolinite $\left(13.8 \mathrm{~m}^{2} \mathrm{~g}^{-1}\right)$. Also, cation exchange capacity is much higher for bentonite $(70.4 \mathrm{meq} / 100 \mathrm{~g})$ than for kaolinite $(19.1 \mathrm{meq} / 100 \mathrm{~g})$. These conclusions are consistent with the literature [39, 40], and therefore it can be considered that the mixture with $30 \%$ bentonite and $10 \%$ lime is the most effective in the metal immobilization.

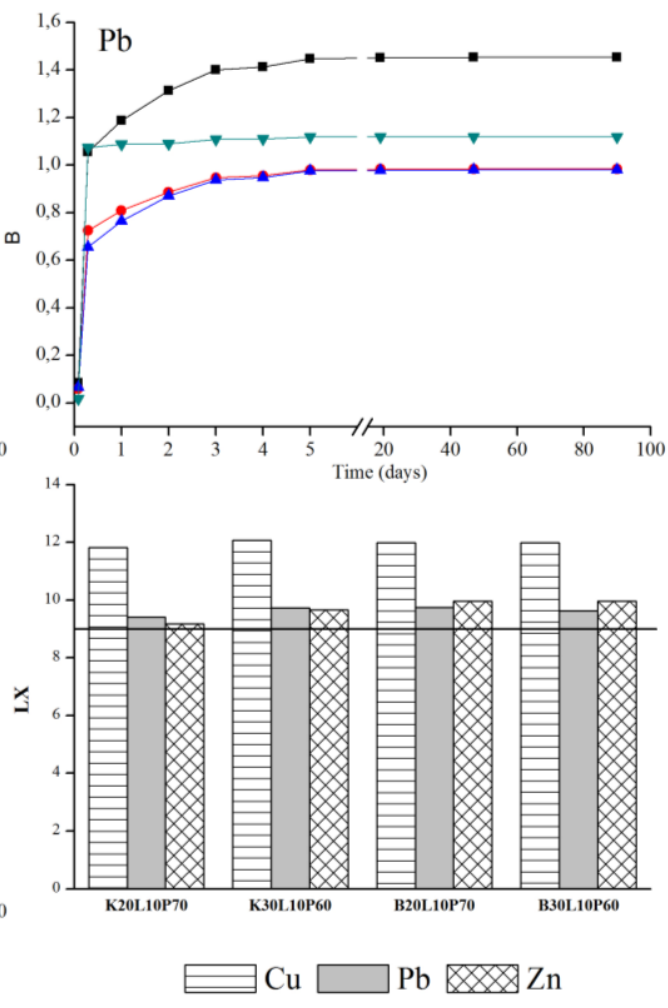

Figure 2 - Cumulative leached metal fractions and mean leachability indexes $(L X)$ from the $S / S$ mixtures

ANS 16.1 leaching model uses Fick's diffusion theory and provides a diffusion rate that can enable the evaluation of the efficiency of the S/S treatment $[23,24]$ based on the determination of diffusion coefficients (De) and leaching index (LX).
Mean values of diffusion coefficients (De) and leaching indexes $(L X)$, defined by equations 1 and 2 were calculated. The average values of the diffusion coefficients ranged from $2.02 \cdot 10^{-12}$ $3.57 \cdot 10^{-12} \mathrm{~cm}^{2} \mathrm{~s}^{-1}$ for $\mathrm{Cu} ; 5.94 \cdot 10^{-10}-1.03 \cdot 10^{-09}$ $\mathrm{cm}^{2} \mathrm{~s}^{-1}$ for $\mathrm{Pb}$ and $5.41 \cdot 10^{-10}-1.62 \cdot 10^{-09} \mathrm{~cm}^{2} \mathrm{~s}^{-1}$ for 
Zn. According to Nathwani and Phillips, 1980 [41], diffusion coefficients for metals from the $S / S$ mixture can generally range from values for highly mobile metals, about $1 \cdot 10^{-05} \mathrm{~cm}^{2} \mathrm{~s}^{-1}$, to $1 \cdot 10^{-15} \mathrm{~cm}^{2} \mathrm{~s}^{-1}$ for practically immobilized metals in the $\mathrm{S} / \mathrm{S}$ mixtures. Based on this we can conclude that in mixtures with a higher proportion of clay $\mathrm{Cu}$ is practically immobilized, while $\mathrm{Pb}$ and $\mathrm{Zn}$ are moderately mobile.
Average $L X$ values were greater than 9 in all examined mixtures for all tested metals (Figure 2). According to the Canadian Agency for Environmental Protection [22] LX values can be taken as criteria for the use and disposal of $S / S$ treated wastes. For $L X$ values above 9, the treatment is considered efficient and $\mathrm{S} / \mathrm{S}$ treated wastes adequate for "controlled use", for example the rehabilitation of quarries, closing the lagoon, as the basis for roads, etc.

- K20L10P70 - K30L10P60 $\quad$ B20L10P70 $\quad \boldsymbol{\nabla}$ B30L10P60
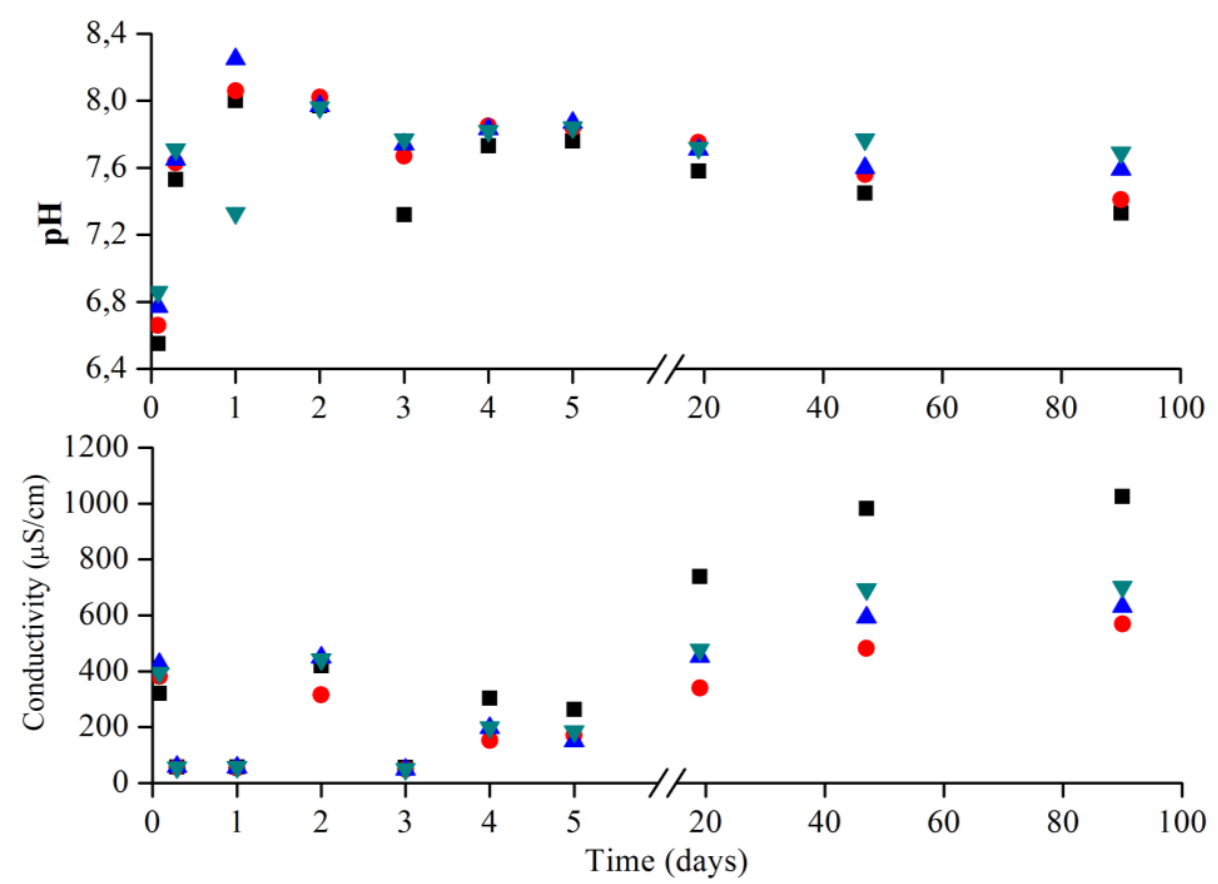

Figure 3 - $\mathrm{pH}$ and conductivity measurements of collected leachates in proposed time periods

Results of $\mathrm{pH}$ and conductivity of the leachates measured after every renewal are shown in Figure 3. $\mathrm{pH}$ values of the leachates were within a range of 6.55-8.25. At the beginning the $\mathrm{pH}$ values were slightly lower as the treated sludge is acidic in nature (originates from sulphuric acid production and it is previously used in acidic Fenton system). Then in the first and second day the alkalinity has been released from the sample, dye to the presence of lime and clays. In the following period the values have stabilized and were around 7.5, due to mutual neutralization of the present materials, indicating that the leachates are not aggressive and corrosive in nature. Observing different mixtures it was concluded that $\mathrm{pH}$ values were not greatly affected by increased portion of the sludge [7, 42]. In a similar manner conductivity was lower at the beginning of the test as the leachates were renewed every day. As the time intervals became larger the conductivity increased, but eventually stabilized, probably due to chemical stabilization of the mixtures and establishment of the equilibrium state of different chemical species in the leachate. These results are in good correlation with the metal leaching; as metals are mostly leached in the first days of the treatment while as time passed leaching became practically negligible.

\subsection{Characterization of $S / S$ mixtures}

In Figure $4 \mathrm{a}, \mathrm{b}$, and c SEM images of raw sludge sample and S/S mixtures with higher clay content are shown. Raw sludge sample exhibited rough and granular texture with a large amount of open porosity. On the other hand, S/S mixtures represent highly dense and homogeneous microstructure systems which are very helpful for the entrapment of heavy metals. Results of X-ray diffraction analysis on $\mathrm{S} / \mathrm{S}$ mixtures with a higher portion of clays are shown in Figure $4 \mathrm{~d}$ and e. Hematite, magnetite, pyrite and quartz, which are identified in both $S / S$ mixtures, originate from the treated sludge as well as the appropriate clays. In general, formation of pozzolanic components, and the presence of calcite and gypsum, further confirms that these matrices have self-cementing 
Dj. Kerkez et al. Treatment of pyrite cinder sludge after usage in dye degradation - Feasibility study

properties and have good potential to be used as characterized as active silica and active alumina construction materials [27, 43]. The high base line also indicates the existence of amorphous content [44].
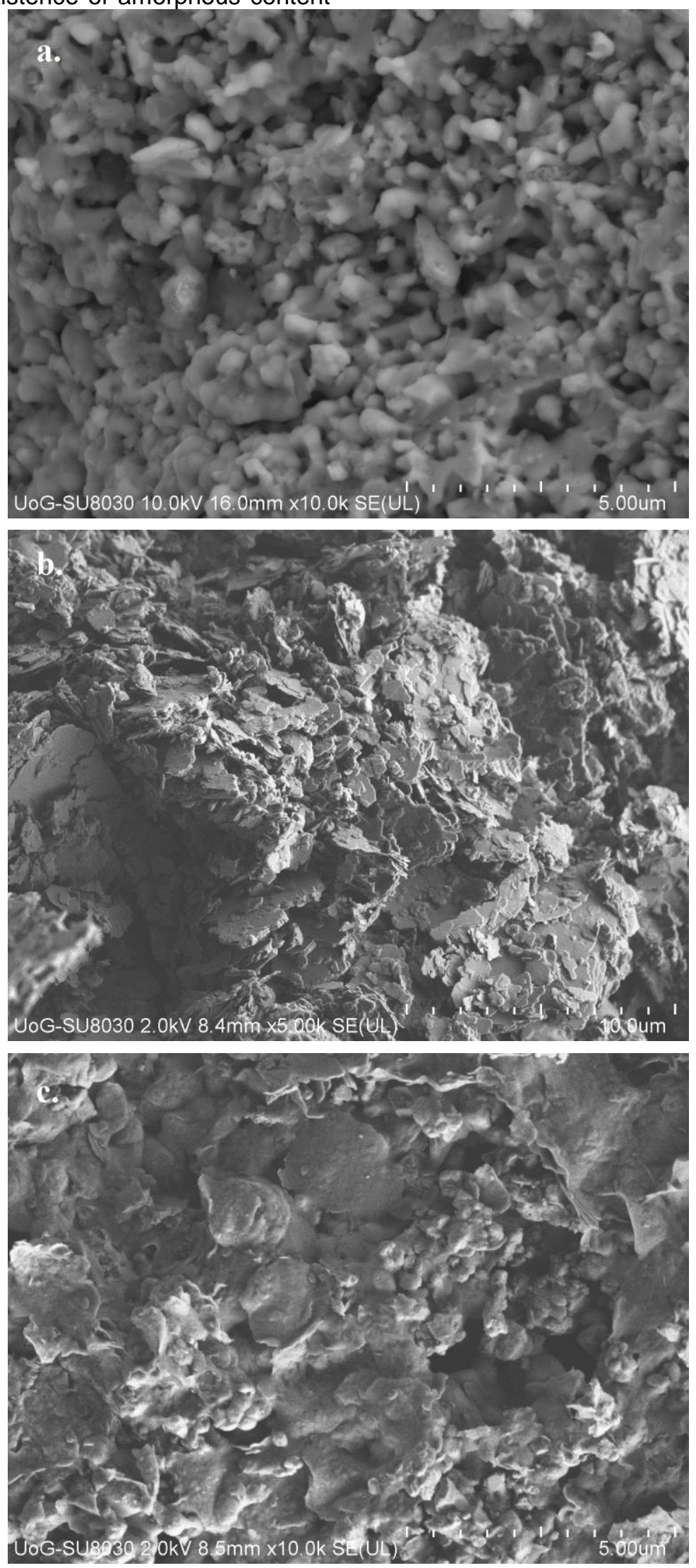

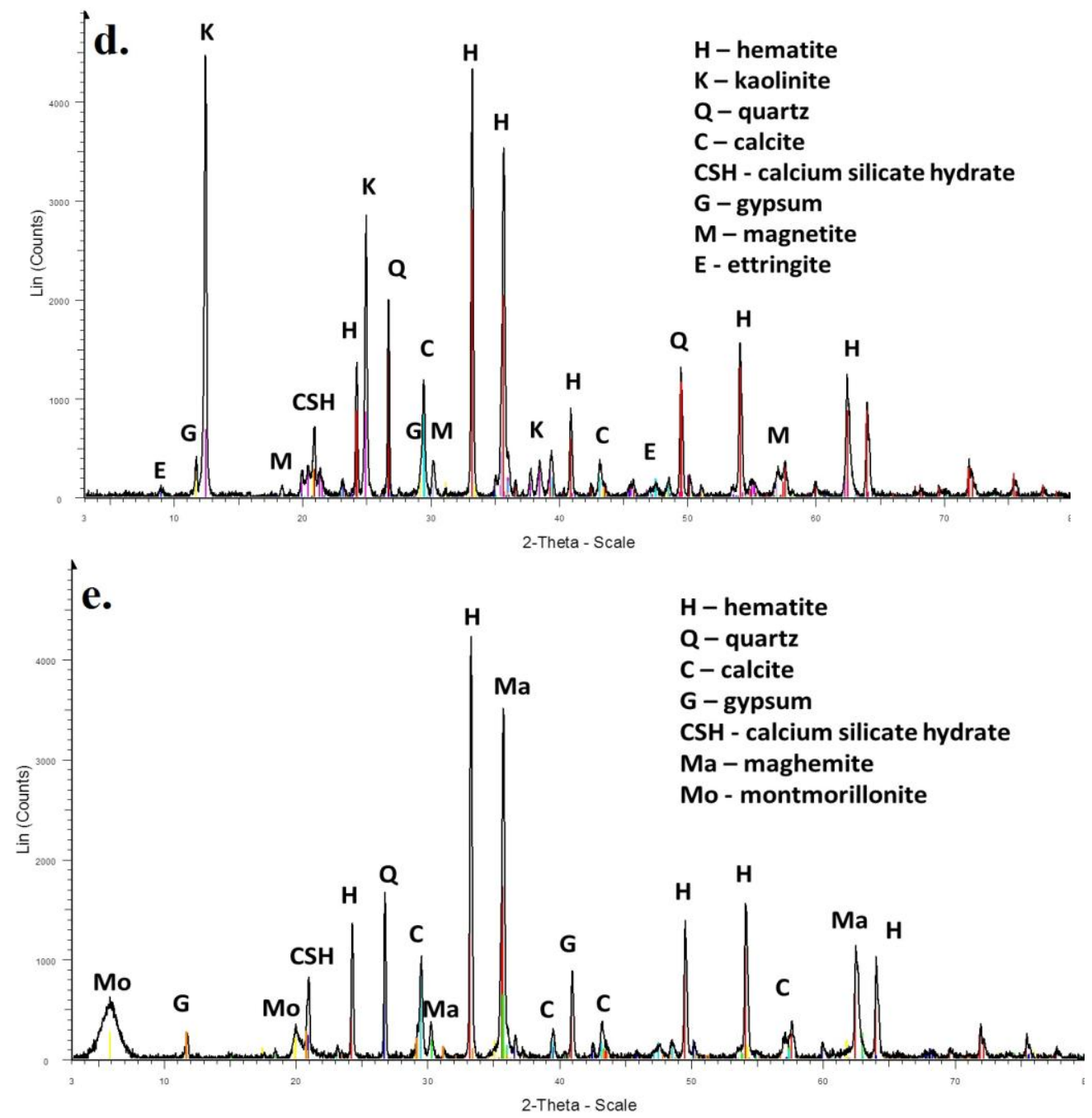

Figure 4 - The morphology selected samples obtained by SEM analysis: a) raw sludge sample,

b) K30L10P60c) B30L10P60; X-ray diffraction analysis (XRD) applied on S/S mixtures

d) K30L10P60, e) B30L10P60

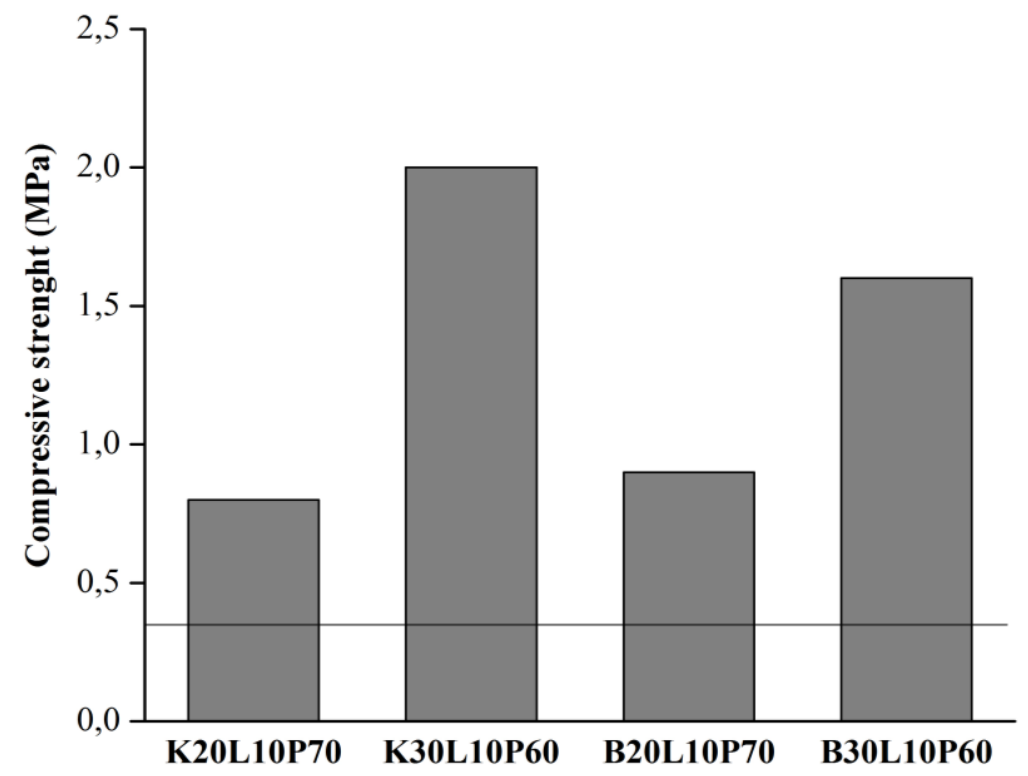

Figure 5 - Compressive strength (MPa) of obtained S/S mixtures after 28 days 
Compressive strength of tested S/S mixtures are shown in Figure 5. According to the EPA, USEPA SW872 1982 [45], S/S materials with hardness greater than $0.35 \mathrm{MPa}$ shall be considered to have sufficient compressive strength. This minimum value is proposed in order to create a stable foundation for the disposal of these materials in landfills.

Compressive strength depends on the quality of pore structure and cementitious materials used. This depends primarily on the type and quantity of the constituents which makes the pore structure (hydratation products) and pozzolanic reactions which take place in the $S / S$ mixtures $[43,46]$. Increase in clay proportion in the S/S mixtures proved to be positive in terms of compressive strength and all obtained mixtures of clay and lime can be used as a base for roads and bulk materials as they all exhibit compressive strength requirement of $0.35 \mathrm{MPa}$. Mixture K30L10P60 showed the highest value of this parameter probably due to presence of the ettringite which plays an important role in the hardening and compressive strength development of these systems [44, 47].

\section{CONCLUSION}

The assessment of the sludge environmental impact, generated in dye effluent treatment, based on the pseudo-total metal content and sequential extraction procedure showed that this waste can be considered as hazardous due to high $\mathrm{Cu}, \mathrm{Pb}$ and $\mathrm{Zn}$ content. The S/S treatment applied, using two different clays and lime, appeared to be effective in the sludge remediation. Sequential extraction procedure indicated that after the treatment there was a significant change in metal distribution. Namely, after the S/S treatment, metal content in soluble and exchangeable phase decreased and consequently the environmental risk was reduced. Semi-dynamic leaching test revealed that the presence of binders and the increase in the clays proportion yielded a decrease of both leachability and diffusion coefficient, and on the other hand, the increase of LX value. SEM and XRD analyses confirmed the formation of dense microstructure and pozzolanic compounds in S/S samples, therefore only small amounts of metals would be expected to leach into the environment over time. From the aspect of compressive strength analysis, produced S/S materials are viable for safe disposal and can also be considered as acceptable for "controlled utilization". These results may justify the application of this remediation procedure, especially when it comes to treating materials containing a mixture of pollutants. This kind of waste treatment is advantageous from both environmental and economic point of view, because in this way hazardous industrial wastes are immobilized and stabilized using abundant and low-cost binders. These results represent a promising type of solution in sustainable waste management.

\section{Acknowledgement}

This paper has been produced with the financial assistance of the Ministry of Education, Science and Technological Development of the Republic of Serbia (projects No. III43005 and TR37004).

\section{REFERENCES}

[1] H.Che, S.Bae, W.Lee (2011) Degradation of trichloroethylene by Fenton reaction in pyrite suspension, Journal of Hazardous Materials, 185, 1355-1361.

[2] M.Bečelić-Tomin, B.Dalmacija, Lj.Rajić, D. Tomašević, Dj.Kerkez, M.Watson, M. Prica (2014) Degradation of Anthraquinone Dye Reactive Blue 4 in Pyrite Ash Catalyzed Fenton Reaction, Scientific World http://dx.doi.org/10.1155/2014/234654.

[3] M.Bečelić-Tomin, B.Dalmacija, D.Tomašević, J. Molnar, Lj.Rajić (2013) Primena piritne izgoretine u mikrotalasnom Fenton procesu obezbojavanja rastvora sintetske boje, Hemijska Industrija, 67, 399-409.

[4] A.M.Álvarez-Valero, R.Sáez, R.Pérez-López, J.Delgadoa, J.M.Nieto (2006) Evaluation of heavy metal bio-availability from Almagrera pyrite-rich tailings dam (Iberian Pyrite Belt, SW Spain) based on a sequential extraction procedure, Journal of Geochemical Exploration, 102, 87-94.

[5] N.Tugrul, E.M.Derun, M.Piskin (2006) Effects of calcium hydroxide and calcium chloride addition to bentonite in iron ore pelletization, Waste Management \& Research, 24, 446-455.

[6] N.Tugrul, E.M.Derun, M.Piskin (2007) Utilization of pyrite ash wastes by pelletization process, Powder Technology, 176, 72-76.

[7] D.Fatta, A.Papadopoulos, N.Stefanakis, M.Loizidou, C.Savvides (2004) An alternative method for the treatment of waste produced at a dye and a metalplating industry using natural and/or waste materials, Waste Management \& Research, 22(4), 234-239.

[8] M.Dalmacija, B.Dalmacija, D.Krčmar, M.Prica, Lj. Rajić, S.Rončević, O.Gavrilović (2012) Solidifikacija/ stabilizacija sedimenta vodotoka Krivaja zagađenog metalima, Hemijska Industrija, 66, 469-478.

[9] A.Gailius, B.Vacenovska, R.Drochytka (2012) Hazardous Wastes Recycling by Solidification Stabilization Method, Medziagotyra, 16, 165-169.

[10] S.Ucaroglu, I.Talinli (2012) Recovery and safer disposal of phosphate coating sludge by solidification/stabilization, Journal of Environmental Management, 105, 131-137.

[11] C.N.Mulligan, R.N.Yong, B.F.Gibbs (2001) An evaluation of technologies for the heavy remediation of dredged sediments, Journal of Hazardous Materials, 85, 145-163. 
[12] M.Chrysochoou, D.Dermatas (2006) Evaluation of ettringite and hydrocalumite formation for heavy metal immobilization: Literature review and experimental study, Journal of Hazardous Materials, 136, 20-33.

[13] O.Yavuz, Y.Altunkaynak, F.Guzel (2003) Removal of copper, nickel, cobalt and manganese from aqueous solution by kaolinite, Water Research, 37 , 948-952.

[14] O.Abollino, A.Giacomino, M.Malandrino, E.Mentasti (2008) Interaction of metal ions with montmorillonite and vermiculite, Applied Clay Science, 38, 277-236.

[15] D.Dermatas, X.Meng (2003) Utilisation of fly ash for stabilization/solidification of heavy metal contaminated soils, Engineering Geology, 70, 377394.

[16] USEPA (United States Environmental Protection Agency) (1986) Cation-exchange capacity of soils (ammonium acetate) METHOD 9080.

[17] USEPA Method 3051a (2007) Microwave assisted acid digestion of sediments, sludges, soils, Revision 1.

[18] M.Sima, B.Dold, L.Frei, M.Senila, D.Balteanu, J.Zobrist (2011) Sulfide oxidation and acid mine drainage formation within two active tailings impoundments in the Golden Quadrangle of the Apuseni Mountains, Romania, Journal of Hazardous Materials, 189, 624-639.

[19] D.Tomašević Pilipović, B.Dalmacija, A.Došić, Đ.Kerkez, N.Slijepčević, M. Bečelić-Tomin (2015) Potential application of nanomaterials in the treatment of contaminated sediment, Zastita Materijala, 56(3), 289-296.

[20] ASTM D1557-00 (2000) Standard test method for laboratory compaction characteristics of soil using modified effort American Society for Testing Materials, Annual Book of ASTM standards: ASTM D1557-91, vol. 4.08. Philadelphia, P: ASTM.

[21] ANS (American National Standard) ANSI/ANS-16.1 (1986) American National Standard for the Measurement of the Leachability of Solidified LowLevel Radioactive Wastes by a Short-Term Tests Procedure, ANSI/ANS-16.1 American National Standards Institute, New York, NY.

[22] Environment Canada (1991) Proposed Evaluation Protocol for Cement-Based Solidified Wastes, Environmental Protection Series, Report No. EPS 3/HA/9.

[23] D.H. Moon, D.Dermatas (2007) Arsenic and lead release from fly ash stabilized/solidified soils under modified semi-dynamic leaching conditions, Journal of Hazardous Mateials, 141, 388-394.

[24] S.Kundu, A.K.Gupta (2008) Immobilization and leaching characteristics of arsenic from cement and/or lime solidified/stabilized spent adsorbent containing arsenic, Journal of Hazardous Materials, 153, 434-443.

[25] USEPA Method 7000B (2007) Flame atomic absorption spectrophotometry, Revision 2.

[26] USEPA Method 7010 (2007) Graphite Furnace Absorption Spectrophotometry, Revision 0.
[27] H.Patel, S.Pandey (2012) Evaluation of physical stability and leachability of Portland Pozzolona Cement (PPC) solidified chemical sludge generated from textile wastewater treatment plants, Journal of Hazardous Materials, (207-208), 56-64.

[28] R. del Valle-Zermeño, J.Formosa, J.M.Chimenos, M.Martínez, A.I.Fernández (2013) Aggregate material formulated with MSWI bottom ash and APC fly ash for use as secondary building material, Waste Management, 33, 621-627.

[29] EPA 658/09 (2009) Supporting documentation for draft Guideline for solid waste: criteria for assessment, classification and disposal of waste, Environment Protection Authority GPO Box 2607Adelaide SA 5001.

[30] C.K.Jain (2004) Metal fractionation study on bed sediments of River Yamuna, India, Water Research 38, 569-578.

[31] Y.Zhou, X.A.Ning, X.Liao, M.Lin, J.Liu, J.Wang (2013) Characterization and environmental risk assessment of heavy metals found in fly ashes from waste filter bags obtained from a Chinese steel plant, Ecotoxicology and Environmental Safety, 95, 130-136.

[32] K.V.Singh, P.K.Singh, D.Mohan (2005) Status of heavy metals in water and bed sediments of river Gomti- a tributary of the Ganga river, India, Environmental Monitoring and Assessment, 105, 43-67.

[33] H.M.Zakir, N.Shikazono, K.Otomo (2008) Geochemical distribution of trace metals and assessment of anthropogenic pollution in sediments of Old Nakagawa River, Tokyo, Japan, American Journal of Environmental Sciences, 4(6), 661- 672.

[34] M.Rawat, A.Ramanathan, V.Subramanian (2009) Quantification and distribution of heavy metals from small-scale industrial areas of Kanpur city, India, Journal of Hazardous Materials, 172, 1145-1149.

[35] P.C.Ryan, S.Hillier, A.J.Wall (2008) Stepwise effects of the BCR sequential chemical extraction procedure on dissolution and metal release from common ferromagnesian clay minerals: a combined solution chemistry and X-ray powder diffraction study, Science of The Total Environment, 407(1), 603-614.

[36] R.Larios, R.Fernández-Martínez, R.Álvarez, I. Rucandio (2012) Arsenic pollution and fractionation in sediments and mine waste samples from different mine sites, Science of the Total Environment, 431, 426-435.

[37] C.Jing, X.Meng, G.P.Korfiatis (2004) Lead leachability in stabilized/solidified soil samples evaluated with different leaching tests, Journal of Hazardous Mateials, 114, 101-110.

[38] M.J.Quina, J.C.Bordado, R.M.Quinta-Ferreira (2009) The influence of $\mathrm{pH}$ on the leaching behavior of inorganic components from municipal solid waste APC residues, Waste Management, 29, 2483-2493.

[39] D.H.Moon, D.Dermatas (2006) An evaluation of lead leachability from stabilized/solidified soils under modified semi-dynamic leaching conditions, Engineering Geology, 85, 67-74. 
[40] D.Tomašević, M.Dalmacija, M.Prica, B.Dalmacija, Dj.Kerkez, M.Bečelić-Tomin, S.Rončević (2013) Use of fly ash for remediation of metals polluted sediment - Green remediation, Chemosphere, 92(11), 1490-1497.

[41] J.S.Nathwani, C.R.Phillips (1980) Leachability of Ra-226 from uranium mill tailings consolidated with naturally occurring materials and/or cement: II. Analysis based on mass transport equation, Water, Air and Soil Pollution, 14, 389-402.

[42] C.S.Poon, K.W.Lio, C.I.Tang (2001) A systematic study of cement/PFA chemical stabilisation/ solidification process for the treatment of heavy metal waste, Waste Management \& Research, 19(4), 276-283.

[43] M.Erdem, A.Özverdi (2011) Environmental risk assessment and stabilization/solidification of zinc extraction residue: II. Stabilization/solidification, Hydrometallurgy, 105, 270-276.

[44] W.Liu, H.Hou, C.Zhang, D.Zhang (2009) Feasibility study on solidification of municipal solid waste incinerator fly ash with circulating fluidized bed combustion coal fly ash, Waste Management \& Research, 27(3), 258-266.

[45] Guide to disposal of chemically stabilized and solidified wastes, U.S. EPA SW872, (1982).

[46] V. Zivica (1997) Hardening and properties of cement-based materials incorporating heavy metals oxides, Materials Science and Engineering, B 20, 677-683.

[47] M.Katsioti, N.Katsiotis, G.Rouni, D.Bakirtzis, M.Loizidou (2008) The effect of bentonite/cement mortar for the stabilization/solidification of sewage sludge containing heavy metals, Cement and Concrete Composites, 30, 1013-1019.

\title{
IZVOD
}

\section{TRETMAN MULJA PIRITNE IZGORETINE NAKON UPOTREBE U DEGRADACIJI BOJA - STUDIJA IZVODLJIVOSTI}

Tokom poslednjih nekoliko godina "zeleni" koncept u upravljanju opasnim otpadom dobija sve veći značaj. Ovaj termin se odnosi na procese $i$ aktivnosti koje imaju mali ili zanemarljiv uticaj na životnu sredinu. Cilj ove studije je da se sistematski kvantifikuju fizičke $i$ hemijske karakteristike solidifikovanog i stabilizovanog (S/S) mulja dobijenog u tretmanu efluenta koji sadrži boje, kada je piritna izgoretina upotrebljena kao izvor katalitičkog gvožđa u modifikovanom heterogenom Fenton procesu. S/S tretman je izveden korišćenjem dve gline (kaolinit $i$ bentonit) $i$ kreča u cilju imobilizacije $\mathrm{Cu}, \mathrm{Pb}$ and $\mathrm{Zn}$ prisutnih u mulju. Mikrotalasna sekvencijalna ekstrakcija je korišćena za procenu potencijalne mobilnosti metala i rizika po životnu sredinu. U cilju utvrđivanja dugoročnog ponašanja $S / S$ smeša izveden je semi-dinamički ANS 16.1 test izluživanja. Efektivnost S/S tretmana procenjena je merenjem kumulativne frakcije izluženih metala, efektivnog difuzionog koeficijenta - De i indeksa izluživanja - LX. Skenirajuća elektronska mikroskopija (SEM) i X-ray difrakcija (XRD) su korišćene da razjasne mehanizam odgovoran za imobilizaciju $\mathrm{Cu}$, Pb i Zn. Ova analiza je potvrdila formiranje kompaktnog matriksa i pozolaničkih produkata. Merenja pritisne čvrstoće su takođe dokazala efikasnost tretmana. Može se zaključiti da S/S tehnika ima značajan potencijal u rešavanju problema sa opasnim industrijskim otpadom $i$ njegovim bezbednim odlaganjem.

Ključne reči: industrijski otpad, dugoročno izluživanje, jeftina veziva, pritisna čvrstoća, održivo upravljanje otpadom

\author{
Naučni rad \\ Rad primljen: 26.03.2016. \\ Rad prihvaćen: 3.05.2016. \\ Rad je dostupan na sajtu: www.idk.org.rs/casopis
}

